\title{
Search for $R p v 3$ and $R p v 12$ genes in genotypes of table and seedless grape varieties using DNA-markers
} Makarkina M.V., Ilnitskaya E.T., Tokmakov S.V.

Federal State Budget Scientific Institution "North Caucasian Federal Scientific Center of Horticulture, Viticulture, Winemaking", Krasnodar, Russia

E-mail: ilnitskaya79@mail.ru

Key message. DNA-marker analysis of grape genotypes for the presence of downy mildew resistance genes Rpv3 and Rpv12 was performed. Table and seedless grapes varieties and forms carring these resistance genes were identified according to the DNA-marker evaluation.

Keywords: grapes, DNA-markers, downy mildew resistance genes, Rpv3, Rpv12

The biotrophic oomycete of Plasmopara viticola Berl.et de Toni. causes one of the most common and harmful diseases of grapes in the world - downy mildew. Cultivation of resistant grape varieties allows to restrain the active development of the pathogen, to reduce the number of treatments of plantings with pesticides, which is particularly important for viticulture of table varieties. Genotypes that are resistant to downy mildew belong to the grapes of North America and Asia. Currently, more than 20 loci of grape resistance to $P$. viticola are known. The genes Rpv3 (inherited from North American species) and Rpv12 (derived from $V$. amurensis) are among the most effective and have an additive effect. Creating resistant table varieties with high consumer properties is an urgent task of modern grape breeding. Seedless table varieties are particularly in demand. The purpose of this work is to search for donors of downy mildew resistance genes Rpv3 and Rpv12 in the gene pool of table and seedless grape varieties and forms using DNA-markers. The study is performed by PCR with analysis of the results on an automatic genetic analyzer ABI Prism 3130. Microsatellite markers recommended for DNA- identification of the studied genes are used: Rpv3 - UDV305, UDV737 (Di Gaspero et al., 2012), Rpv12 - UDV343, UDV360 (Venuti et al., 2013). Seedless and table grapes genotypes that are promising for use in breeding as initial forms for a number of economically valuable traits were included in the study. As controls, we used the DNA of varieties in which these genes were found, according to published data. According to the results of DNA-marker analysis, table varieties and forms were determined, including seedless ones, whose genotypes contain alleles of genes that determine resistance to downy mildew. One genotype with both Rpv3 and Rpv12 was also identified - the Rochefort grape variety. The obtained molecular and genetic data correspond to information about the pedigree of varieties and forms. The results of this work can be used in the development of breeding programs for creating grape forms with combined resistance genes.

The reported study was funded by RFBR and the Administration of Krasnodar Region, according to the research project № 19-416-230051 r_a.

\section{Поиск генов $R p v 3$ u Rpv12 в генотипах столовых и бессемянных сортов винограда с помощью ДНК-маркеров Макаркина М.В., Ильниикая Е.T., Токмаков С.В. \\ Федеральное государственное бюджетное научное учреждение «Северо-Кавказский федеральный научный центр садоводства, виноградарства, виноделия, Краснодар, Россия}

Аннотация. Выполнен ДНК-маркерный анализ генотипов винограда на наличие генов устойчивости кмилдью Rрv3 и Rpv12. Выявлены столовые и бессемянные сорта и формы винограда, несущие указанные гены устойчивости по данным ДНК-маркерной оценки.

Ключевые слова: виноград, ДНК-маркеры, гены устойчивости кмилдью, Rpv3, Rpv12

Биотрофный оомицет Plasmopara viticola Berl.et de Toni. вызывает одно из наиболее распространенных и вредоносных заболеваний винограда в мире - милдью. Возделывание устойчивых сортов винограда позволяет сдерживать активное развитие патогена, сокращать количество обработок насаждений пестицидами, что особо значимо для виноградарства столовых сортов. Генотипы, обладающие устойчивостью к милдью, принадлежат винограду Северной Америки и Азии. В настоящее время известно более 20 локусов устойчивости винограда к $P$. viticola. Гены Rpv3 (наследуется от северо-американских видов) и Rpv12 (происходит из V. amurensis) являются одними из наиболее эффективных и имеют аддитивный эффект. Создание устойчивых столовых сортов с высокими потребительскими свойствами - актуальная задача современной селекции винограда. Бессемянные столовые сорта особо востребованы. Цель выполняемой работы - поиск доноров генов устойчивости к милдью $R p v 3$ и $R p v 12$ в генофонде столовых и бессемянных сортов и форм винограда с помощью ДНК-маркеров. Исследование проводится методом ПЦР с анализом результатов на автоматическом генетическом анализаторе ABI Prism 3130 . В paботе использованы микросателлитные маркеры, рекомендованные для ДНК-идентификации изучаемых генов: Rpv3 UDV305, UDV737 (Di Gaspero et al., 2012), Rpv12 - UDV343, UDV360 (Venuti et al., 2013). В исследование были включены бессемянные и столовые генотипы винограда, перспективные для использования в селекции в качестве исходных форм по ряду хозяйственно-ценных признаков. В качестве контролей использовали ДНК сортов, в которых обнаружены указанные гены, согласно опубликованным данным. По результатам ДНК-маркерного анализа определены столовые сорта и формы, в том числе и бессемянные, в генотипах которых присутствуют аллели генов, определяющие устойчивость к милдью. Также выявлен один генотип, обладающий и $R p v 3$ и $R p v 12$ - сорт винограда «Рошфор». Полученные молекулярно-генетические данные соответствуют сведениям о родословной сортов и форм. Результаты работы могут быть использованы при разработке селекционных программ по созданию форм винограда с объединенными генами устойчивости.

Работа выполнена при финансовой поддержке РФФИ и Администрации Краснодарского края в рамках научного проекта № 19-416-230051 p_a. 